\title{
La movilidad de los objetos tecnocientíficos: un ejemplo de biopolítica a través de las patentes ${ }^{1}$
}

\section{Technoscientific's objets mobility: a biopolitical example trough patents}

\author{
Igor SÁDABA RoDRÍGUEZ \\ Universidad Complutense de Madrid \\ igor.sadaba@cps.ucm.es
}

Recibido: 16.02.2012

Aprobado definitivamente: 02.10 .2012

\section{RESUMEN}

Hasta ahora la mayoría de estudios sobre movilidad y/o biopolítica se han centrado en la gestión política de los sujetos (flujos migratorios, instituciones de control, turismo internacional, gubernamentalidad de los procesos globales, etc.). Por una parte, el paradigma de la movilidad (Urry y la escuela de Lancaster) ha abordado un abanico disperso e inconexo de fenómenos móviles introduciendo tímidamente las cuestiones del poder. De otra, las reflexiones biopolíticas contemporáneas en el seno de las Ciencias Sociales han operado siempre con sujetos de carne y hueso excluyendo de sus reflexiones el mundo de los objetos (tal y como reclamaría la Teoría del Actor-Red y otras miradas sociológicas). En este artículo se intenta esbozar un marco de comprensión de procesos biopolíticos relacionados con la movilidad de ciertos objetos o redes de objetos/sujetos; en concreto a través de los títulos de propiedad ad hoc sobre objetos tecnocientíficos, las patentes. Gracias a ciertos acontecimientos históricos de finales del siglo XIX y principios del siglo XX se va construyendo un entramado patentista internacional (exposiciones mundiales, tratados bilaterales, acuerdos continentales, etc.), que junto con determinados elementos actuales relacionados con la globalización de las propiedades inmateriales tecnocientíficas (acuerdos TRIPs y similares en el caso biotecnológico o agroalimentario), servirán como ejemplos o estudios de caso para ilustrar la dinámica biopolítica generada por la movilidad estratégica de objetos científicos y tecnológicos (producto de un régimen de apropiación basado en títulos internacionales sobre genes, fórmulas químicas, biomasa, especies vegetales o animales, alimentos, transgénicos, etc.).

Palabras clave: Biopolítica, movilidad, patentes, propiedad intelectual, genoma humano.

\begin{abstract}
So far, most social studies of mobility and/or bio-politics have focused on the political management of the subjects (migration, control institutions, international tourism, global governmentality processes, etc.).. On the one hand, the paradigm of mobility (Urry and the Lancaster School) has addressed a range of scattered and disjointed human phenomena introducing timidly issues of power. Otherwise, the contemporary biopolitical reflections within the social sciences have always operated with flesh and blood subjects excluding the world of objects (such as claim and complain the actor-network theory (ANT) and other sociological eyes). This article attempts to outline a framework for understanding biopolitical processes related to the mobility of certain objects or networks of objects/subjects; in particular through the ad hoc property titles on technoscientific objects (the patents). Due to certain historical events of the late nineteenth and early twentieth century a international patents network is built (world exhibitions, bilateral, continental agreements, etc...)
\end{abstract}

\footnotetext{
${ }^{1}$ Desearía agradecer la labor del coordinador del número Ignacio Mendiola por su paciencia y buen hacer y de los evaluadores anónimos por su sugerentes y constructivos comentarios que han ayudado a mejorar y pulir este artículo.
} 
and together with elements related to the current globalization of intangible techno-scientific properties (TRIPs agreements and the case of biotechnologies or food industries) will serve as examples or case studies to illustrate the dynamics generated by the biopolitical strategic mobility of scientific and technological objects (outcomes of an ownership regime based on international titles genes, chemical formulas biomass, plant or animal species, food, biotech, etc.).

KEYwORDs: Biopolitics, mobility, patents, intelectual property, human genome.

\section{SUMARIO}

1.A modo de introducción: Biopolítica y Movilidad. 2.Primeros encuentros entre Biopolítica y movilidad. 3.Una propuesta de encuentro distinta: las patentes sobre genes humanos. 4.Innovación como discurso biopolítico. 5.Biopolítica y control sociotécnico (movilidad de los objetos tecnocientíficos). 6.Conclusiones. 


\section{A MODO DE INTRODUCCIÓN: BIOPOLÍTICA Y MOVILIDAD}

La tradición de estudios que se enmarca en eso que denominamos "biopolítica" y que bebe de diferentes fuentes, entre ellas de las sobresalientes intuiciones foucaultianas, ha tendido a abordar generalmente dicha cuestión desde la gestión y administración moderna de sujetos y poblaciones. La regulación (sutil) de todos los ámbitos humanos (en sus mismas condiciones vitales) sería el modo actual de existencia del poder político en contraposición a épocas más antiguas basadas en la violencia directa y el gobierno manu militari. La biopolítica vendría a rotular o atrapar en un solo significante un nuevo método de racionalidad política y ordenación de las poblaciones que sustituye la vieja represión coercitiva directa por una reglamentación extensa y constante. No obstante, este neologismo foucaultiano, en apariencia simple, se ha utilizado en la literatura de las ciencias sociales en referencia a conceptos muy distintos y no siempre coincidentes (en ocasiones antitéticos), bifurcándose en cada nuevo autor y fomentando labores de exégesis permanente (casi como los mismos textos de Marx). La aportación del filósofo francés estribaba en dar fundamento teórico a una serie de operaciones sociopolíticas (de tecnologías de control rutinario sobre cuerpos) que trataban de regular "haciendo vida" (construyendo sujetos y relaciones) y no destruyendo vida (violencia política manifiesta) tal y como se imponía en los regímenes de la era premoderna ${ }^{2}$.

A pesar de que este tipo de definiciones dentro del campo de la filosofía política conlleven cierta ambigüedad, numerosos autores han reconocido hoy en día el valor de la noción de biopolítica, en tanto registra una ruptura histórica en las formas de gobierno (racionalidades políticas) y permite designar la existencia de un poder específicamente moderno. El amanecer de un tiempo en el que el Estado se interesa por el número de habitantes de su territorio, por su salud, por las medidas de reproducción fami- liar, etc. puede ser tildado de cambio cualitativo y cesura (histórica, ya que Foucault inscribe todo ello en una cierta genealogía de la governementalité) con respecto a sus predecesores. En cualquier caso, cabe señalar que esta mutación en los modos y maneras de ejercicio del poder no emerge de la nada (ex nihilo) sino que está muy emparentada con el despuntar liberal y el primer capitalismo industrial, ávido de una fuerza de trabajo dispuesta y dócil (Gaudemar, 1981 y 1991). Una biopolítica de las poblaciones es funcional y requisito indispensable para un régimen fabril extendido en consonancia con la mercantilización general que el capitalismo necesitaba en pleno siglo XIX (Foucault, 1996). La biopolítica, entonces, es el efecto de un programa liberal para la construcción de un "espacio de libertad vigilada a fin de hacer posible los mecanismos de mercado" (Pincheira, 2008: 167).

Diversos pensadores en la órbita de la ciencia política, la sociología o la filosofía han estirado con fruición estas reflexiones o simientes intelectuales foucaultianas (véase a Agamben, Espósito o similares) resultando llamativo el imán que ha supuesto el término (nacido en las regiones filosóficas pero ya migrado y adoptado en numerosos terrenos distantes de las ciencias sociales). No obstante, la idea, que nació para evidenciar esa ruptura histórica, no siempre ha conseguido sacudirse cierto aura de indefinición y vaguedad, permaneciendo siempre en un limbo de imprecisión y oscuridad a medio camino entre una aplicación omnipresente (la biopolítica está en todas partes) y una ontología cosificadora (la biopolítica es algo único) (Mendiola, 2009: 7). Sin embargo, la conexión entre política y vida ha atrapado o atraído a no pocas generaciones, seguramente porque ha permitido realizar una reunión o ligazón necesaria entre ciertas políticas y las metamorfosis del Estado con procesos vitales y experiencias contemporáneas. Pareciera que era necesaria una articulación teórica entre el poder moderno (su racionalidad, su legitimación) y la vida común: una bisagra

\footnotetext{
${ }^{2}$ No viene mal recordar que "Nacimiento de la biopolítica" (Foucault, 2007) está basado en un curso dictado por Michel Foucault en el Collège de France entre enero y abril de 1979, dando continuidad al curso del año anterior, "Seguridad, territorio, población" (Foucault, 2006) y donde el filósofo francés intenta describir las nuevas formas de gubernamentalidad liberal asociadas a la economía política del siglo XVIII (más específicamente al liberalismo alemán y norteamericano). Aunque la noción de gubernamentalidad comienza a perfilarse alrededor de 1975 (en el curso "Los anormales"), no es hasta las primeras clases del curso de 1978 donde el término adquiere cierta consistencia teórica.
} 
que uniera la gestión racional de capitalismo con las políticas públicas que se instauraron y desarrollaron en el último siglo; una función que puede cumplir el término.

Seguramente, como hemos apuntado, la problemática de un vocablo tan amplio e incisivo como el de biopolítica es que resulta demasiado poco concreto y difuso pero, pudiera simultáneamente apuntar a una pretendida esencialidad muy particular constituyente de lo moderno y posmoderno. Este medio camino entre serlo todo y no ser nada, su carácter fronterizo e inter o multidiscipliar (Mendiola, 2009: 8-9), solo se resuelve ahondando empíricamente en sus contornos y reflexionando colectivamente sobre sus límites y potencias. La volatilidad conceptual del término ha podido generar un rechazo frontal al mismo. En ese sentido, entendemos que es pertinente intersecar la mirada o el enfoque biopolítico con otras temáticas, disciplinas o áreas para encontrar resultantes empíricamente observables y reflexiones enriquecedoras. En ese cruce tangencial, de encuentros y choques entre diferentes materias o tópicos surge la evidencia de la constitución política de lo social. La potencia del pensar biopolítico y del paradigma circundante se materializa cuando visibilizamos sus dispositivos, sus modos de acción o sus cambios (porque no es estática, ni fija, ni inmutable o eterna). El propio Foucault insistió mucho en las derivas históricas y en los cambios temporales de este tipo de estructuras. Son "sus rastros y sus rostros" (Mendiola, 2009) los que dotan de fuerza epistemológica y robustez analítica al intento de comprender la ejecución diaria del poder contemporáneo.

Por otra parte, el así llamado paradigma de la movilidad resulta de una propuesta más puramente sociológica (y no tan filosófica) en el campo de las ciencias sociales anglosajonas (fundamentalmente) que tratan de narrar un mundo esencialmente móvil y donde las dinámicas fluidas se han convertido en norma y no excepción (Lasén, 2006, Urry, 2007 y Urry y Elliot, 2010). Lo positivo de esta corriente, espoleada por los trabajos de J. Urry y el Mobilities Research Group de la universidad de Lancaster, es que sirve de paraguas interpretativo para un conjunto de fenómenos sociales amplio y múltiple: migraciones, turismo y viajes, procesos globales, transportes, transformaciones urbanas, nuevas tecnologías, flujos de información, etc. La movilidad, como categoría sociológica cumple una función de reunir y aglutinar elementos dispersos en un esquema teórico coherente (Urry, 2007). Las novedades que la noción actual de movilidad comportan para la teoría social exceden el puro modismo nominal (la invención de una etiqueta sugerente) presentando un término que engloba todo un sistema de transacciones, intercambios y procesos sociales complejos (venta, consumo, energía, seguridad, comunicación, etc.) que hasta la fecha eran difíciles (por no decir imposibles en un sentido kuhniano) de pensar globalmente desde las coordenadas de las ciencias sociales. Las teorías sociales decimonónicas y de corte positivista habían abusado de teorías ancladas en objetos duros, estables, asentados y relativamente inalterables. Lo social no dejaba de ser visto como algo monolítico con caracteres y propiedades estáticas donde los sujetos (y objetos) se ubicaban en espacios asignados, permanentes y quietos (clases sociales, instituciones, identidades, grupos, etc.). Los nuevos tiempos traen aparejados una movilidad constitutiva de lo social que abandona esa posición de quietud, parálisis y sedentarismo.

Nos interesa reseñar que, en su descripción del "paradigma de la movilidad" (2007: 44-60), Urry apunta, entre otros lugares, hacia los debates del posthumanismo (Hayles e Ingold, Latour, etc.) al considerar que el centro de la movilidad es la intersección de diversos sistemas donde conviven humanos y no humanos. Así que este autor, en claro guiño latouriano, bajo la proclama de que "nunca hemos sido humanos" (2007: 45) apuesta por un modelo que reconozca la imbricación de sujetos y objetos en unidades superiores ("movimientosespacios"). La noción de "movilidad generalizada" (por parafrasear aquí a la "simetría generalizada" de Michael Callon, 1986 y 1991) tendría sentido en este marco de posthumanismo teórico. La idea de movilidad se centra entonces en el desplazamiento sistemático de personas, bienes o información (o, más bien, agregados heterogéneos de todo ello) que viajan por todo el espacio social en tasas mucho más altas que anteriormente. De esa forma, ya sea a través de la copresencia (face-to face) o de interacciones basadas en la "presencia imaginada", la vida social se construye como alternancia entre el cerca (de otros) y lejos (de otros), en la circulación permanente. Urry reconoce 5 tipos de movilidades que construyen la sociabilidad moderna organizando las relaciones entre objetos y sujetos: i) el viaje corporal 
de individuos, ii) el movimiento físico de objetos, iii) el viaje "imaginario" a través de los medios de comunicación escritos y visuales, iv) los viajes virtuales y v) los viajes comunicativos de información y mensajes (Urry, 2007: 47). A través de ellos, este autor desgrana cómo nuestra ubicación y dinámica móvil predetermina nuestras interacciones y hasta nuestra posición en la estructura social (y viceversa), forjando nuestra identidad, nuestras formas de participación, nuestros niveles de consumo, etc. Aprovecharemos estas reflexiones sobre movilidad sistémica para incluirlas en un intento de comprensión de los modelos de investigación y comercialización contemporáneos de la genética de última generación. Como veremos, Urry se quedará corto (sus tipologías de movilidad son todavía insuficientes) pero será el trampolín para intentar realizar la conexión entre la gestión del poder tecnocientífico y la regulación móvil de ciertos objetos.

\section{PRIMEROS ENCUENTROS ENTRE BIOPOLÍTICA Y MOVILIDAD}

Si la mirada biopolítica requiere, como mencionamos anteriormente, en su huída de la reificación intelectual y la vaguedad teórica, del encuentro empírico con las variedades históricas, con los dispositivos concretos y con los mecanismos contingentes que la constituyen (tal y como hizo el propio Foucault a lo largo de su vida y sus escritos), ¿qué mejor opción que recoger el guante que la movilidad ha lanzado?. Precisamente una de las críticas recibidas por el emprendedor proyecto del paradigma de la movilidad viene a ser, nuevamente, la tendencia parsoniana a la "gran teoría" (Mills) ausente o carente de fundamento empírico. El encuentro entre ambas perspectivas conceptuales no es tan nuevo ni original como uno pudiera pensar. La regulación política de la vida (y de la muerte) a través de sistemas móviles o de la modulación de los movimientos de los sujetos es algo que ya se ha estudiado en algunos casos en relación, por ejemplo, a las migraciones o a la automovilidad y la siniestralidad (Heiber, Moral, Pecharroman y Gordo, 2008). El coche o, mejor dicho, el sistema automovilista condicionan la vida moderna sobremanera. La sociedad capitalista necesita de tal "biodispositivo" para que sus dinámicas se impongan de forma que el sistema de automo- vilidad que encarna el coche (más bien el actante conductor-coche) sería un modelo de biopoder muy claro donde economía, cultura y política convergen. $\mathrm{Y}$ donde la gestión de la población (de su vida y de su muerte) se da la mano con la movilidad tecnológica (y social: son los sujetos que necesitan ir a trabajar, estudiar, socializarse, entretenerse y comprar los que requieren hibridarse con el coche). Un artefacto que aglutina, como "artefacto social total" producción y consumo a la vez. Por un lado un encierro del conductor, cuya subjetividad se construye desde su "manejo de la máquina". Y, por otro, la definición, aparentemente externa de una industria que diseña máquinas cuyas necesidades (revisiones, gasolina, etc.) nos imponen. El coche, un biodispositivo por excelencia, se ha hecho con el monopolio de la vida social legítima: ser individuo en esta sociedad requiere de algún tipo de acceso a la automovilidad que sirve como intermediación universal entre sujetos y objetos. El automóvil constituye parte de las condiciones materiales de existencia social (transporte mecanizado individual) y participa del biogobierno (estratificación social, producción de subjetividad, regulación del espacio urbano, etc.). Aunque pueda resultar anecdótico en un principio, este caso entendemos que ejemplifica versiones tempranas del puente movilidad-política que deberán ser superadas y mejoradas.

Nuestra intención, en cambio, supondrá un cierto viraje, proponiendo un ejemplo muy distinto a considerar. No lo vamos a tratar en profundidad (lo que requeriría un espacio y una dedicación mucho mayor) ya que la intención es traer a colación un modelo de dispositivo biopolítico que no reglamente (y limite) directamente los movimientos humanos (control de fronteras y aduanas, por pensar en alguno). Más bien, nos interesa uno basado en cierta movilidad de las redes tecnocientíficas mediante títulos legales de propiedad que regulan el acceso a las mismas, garantizando la estabilidad de un sistema económico-jurídico que sustenta el comercio globalizado. A diferencia del sistema hombre-coche (visible en su constitución), los bienes intelectuales de la tecnociencia siguen trayectorias móviles cuya modulación resulta original $\mathrm{y}$, en ocasiones, poco visible o evidente. Quizás no consigamos el acoplamiento perfecto pero planteamos una posible vía de investigación a explorar y profundizar donde la co- 
municación entre el plano biopolítico y el paradigma de la movilidad debería ser posible ${ }^{3}$.

\section{UNA PROPUESTA DE ENCUENTRO DISTINTA: LAS PATENTES ${ }^{4}$ SOBRE GENES HUMANOS}

"Los genes serán en el siglo XXI lo que el petróleo, los minerales y los metales fueron en la era colonial e industrial." (J. Rifkin, Entrevista en The Unesco Courier, septiembre 1998).

El secuenciamiento del genoma humano ha sido uno de los más recientes y sonados éxitos de las biotecnologías contemporáneas. Permite adentrarse en un vasto campo de investigación repleto de promesas al alcanzar de lleno la información que codifica nuestra existencia biológica. El Proyecto Genoma
Humano (PGH), plan de investigación a gran escala, destinado a desentrañar dicho código genético, y paradigma de la sociedad biotecnológica tiene para nosotros un interés especialmente sociológico. Aparte de lidiar con un objeto de horizontes originales y desconocidos, el proyecto responde a una estructura insólita: un programa de investigación científica que ha durado más de 10 años, que ha involucrado a más de 18 países y que comenzó desarrollándose principalmente bajo financiación pública (Instituto Nacional de Salud de EEUU y la fundación británica Wellcome Trust) para bifurcarse y pasar a competir, posteriormente, con el capital privado (Celera Genomics, principalmente). En el seno de dicha megainvestigación, ha aflorado toda una gama de controversias sobre la patentabilidad de los genes y del genoma humano en particular donde la cuestión de la movilidad/acceso y gestión política de la vida se han entrelazado como una doble hélice.

Tabla 1: Desarrollo cronológico y selección de datos sobre la génesis y la evolución del PGH (relacionados con el papel de las patentes).

\begin{tabular}{|c|l|}
\hline Año & \multicolumn{1}{|c|}{ Acontecimiento } \\
\hline 1986 & $\begin{array}{l}\text { Congreso en Santa Fe en el que se barrunta la posibilidad de dedicar una partida presupuestaria a } \\
\text { secuenciar el genoma humano por parte del Ministerio de la Energía de EEUU (DOE, Department } \\
\text { of Energy). }\end{array}$ \\
\hline 1987 & $\begin{array}{l}\text { Congreso en el Laboratorio de Cold Spring Harbor en el que los Institutos Nacionales de la Salud } \\
\text { (NIH) de EEUU se suman a la idea. }\end{array}$ \\
\hline 1988 & $\begin{array}{l}\text { Se publican informes de la Oficina de Evaluación Tecnológica del Congreso (OTA) y del Consejo } \\
\text { Nacional de Investigación (NRC) para dar luz verde a la iniciativa. Ese mismo año se establece } \\
\text { la Organización del Genoma Humano (HUGO), como entidad destinada a la coordinación } \\
\text { internacional del proyecto. }\end{array}$ \\
\hline
\end{tabular}

\footnotetext{
${ }^{3}$ De hecho, el propio Foucault ya había intuido esta conexión en algunos de sus textos clásicos (2006) al afirmar que el movimiento es consustancial a las formas de regulación de la vida basadas en lo que él denominaba "dispositivo de seguridad" (nombre temprano que, en esos textos, le da a la superación del dispositivo disciplinario): "Un dispositivo de seguridad -o, en todo caso, el dispositivo del que les he hablado- sólo puede funcionar bien con la condición de que se dé algo que es justamente la libertad, en el sentido moderno que esta palabra adopta en el siglo XVIII: ya no las franquicias y los privilegios asociados a una persona, sino la posibilidad de movimiento, desplazamiento, proceso de circulación de la gente y las cosas" (2006: 71). Prosigue con otra cita sugerente: "Ahora bien, me parece que a través de los fenómenos obviamente muy parciales que traté de indicar vemos aparecer un problema muy distinto: ya no fijar y marcar el territorio, sino dejar fluir las circulaciones, controlarlas, seleccionar las buenas y las malas, permitir que la cosa se mueva siempre, se desplace sin cesar, vaya perpetuamente de un punto a otro, pero de manera tal que los peligros inherentes a esa circulación queden anulados. Ya no la seguridad del príncipe y su territorio, sino la seguridad de la población y, por consiguiente, de quienes gobiernan" (2006: 86).

${ }^{4}$ En otros lugares se han tratado otros casos similares tales como las patentes sobre transgénicos (Mendiola, 2006), semillas (Larrión, 2009) o sobre medicamentos (Sádaba, 2008).
} 


\begin{tabular}{|c|c|}
\hline 1990 & $\begin{array}{l}\text { El Proyecto Genoma Humano (PGH) arranca oficialmente en los Estados Unidos con un } \\
\text { presupuesto superior a } 2.200 \text { millones de euros y un plazo de } 15 \text { años, con el objetivo de analizar } \\
\text { molecularmente la herencia genética humana. Comienza bajo la dirección del premio Nobel } \\
\text { James Watson. }\end{array}$ \\
\hline 1991 & $\begin{array}{l}\text { Se establece el Human chromosome mapping data repository (GDB). En julio de ese año, Craig } \\
\text { J. Venter, entonces en los NIH, reconoce públicamente que dicha institución ha solicitado las } \\
\text { patentes de fragmentos de ADN de células del cerebro secuenciadas en su laboratorio (casi } \\
2500 \text { segmentos de ADN distintos). J. Watson, director en ese momento del PGH, se opone } \\
\text { abiertamente. }\end{array}$ \\
\hline 1992 & $\begin{array}{l}\text { Se anuncian las Guidelines (guías de actuación) para la distribución de datos y compartición de } \\
\text { recursos por parte del DOE y los NIH. Son las instrucciones y normas a seguir con cada dato } \\
\text { genético obtenido. } \\
\text { En abril, Watson dimite como director del NCHGR, siendo sustituido por Francis Collins. } \\
\text { En junio, Venter abandona los NIH y crea The Institute for Genomic Research (TIGR), que es } \\
\text { financiado con } 125 \text { millones de dólares por SmithKline Beecham a través de la compañía Human } \\
\text { Genome Sciences (HGS). }\end{array}$ \\
\hline 1994 & $\begin{array}{l}\text { Se publica el primer producto legislativo estadounidense del PGH, la Genetic Privacy Act, cuyo } \\
\text { propósito es regular la colección, el análisis, el archivo y uso de muestras de ADN e información } \\
\text { genética obtenidos de dicho proyecto. } \\
\text { Craig Venter, a través del TIGR, dirige y encabeza el desciframiento de la secuencia completa del } \\
\text { genoma de un organismo entero, la bacteria } H \text {. influenzae. }\end{array}$ \\
\hline 1995 & Se publica el mapa físico del genoma humano (investigadores franceses y americanos). \\
\hline 1996 & $\begin{array}{l}\text { Los participantes en el PGH se ponen de acuerdo, en una Conferencia en las Bermudas, sobre } \\
\text { las políticas de distribución de datos derivados del secuenciamiento (Sequencing Data Release } \\
\text { Policies Bermuda Conference). Se acuerda dar a conocer en } 24 \text { horas, en una base de datos } \\
\text { pública, las secuencias del genoma humano que se vayan obteniendo. }\end{array}$ \\
\hline 1997 & $\begin{array}{l}\text { La UNESCO adopta su Declaración Universal del Genoma Humano y los Derechos Humanos el } \\
11 \text { de noviembre de } 1997 \text { (Universal Declaration on the Human Genome and Human Rights). Su } \\
\text { artículo } 4 \text { reconoce que "El genoma humano en su estado natural no puede dar lugar a beneficios } \\
\text { pecuniarios"; el artículo 12.a afirma que "Toda persona debe tener acceso a los progresos de la } \\
\text { biología, la genética y la medicina en materia de genoma humano, respetándose su dignidad } \\
\text { y derechos" y el artículo } 19 \text { (sección IV) se compromete a "fomentar el libre intercambio de } \\
\text { conocimientos e información científicos en los campos de la biología, la genética y la medicina.". } \\
\text { El TIGR rompe sus relaciones con HGS por razones de política de publicación. }\end{array}$ \\
\hline 1998 & $\begin{array}{l}\text { Se crea Celera Genomics con la intención de secuenciar al máximo el genoma humano en tres } \\
\text { años utilizando recursos generados en el PGH y un método especial (whole-genome shotgun). } \\
\text { Celera Genomics es una corporación resultante de la unión de Applera Corp. y TIGR que avisa } \\
\text { públicamente que su política de acceso a los datos no seguirá la Declaración de las Bermudas. } \\
\text { A su vez, Celera concretó un acuerdo con Applied Biosytems para la comercialización de los } \\
\text { resultados de sus hallazgos. }\end{array}$ \\
\hline
\end{tabular}




\begin{tabular}{|c|c|}
\hline 1998 & $\begin{array}{l}\text { Como respuesta Wellcome Trust anuncia que duplica su dotación económica llegando a soportar } \\
\text { una tercera parte del costo total del proyecto público. Además, NIH y dicha entidad bloquean la } \\
\text { colaboración propuesta entre Celera y DOE. } \\
\text { La ONU adopta la Declaración Universal sobre el Genoma Humano y los Derechos Humanos, } \\
\text { texto elaborado por la UNESCO. Proclama además que "el genoma humano no debe ser } \\
\text { comercializado" (El País, Sociedad, 9/12/1998). }\end{array}$ \\
\hline 1999 & $\begin{array}{l}\text { Se anuncia el } 1 \text { de diciembre la primera secuencia completa de un cromosoma humano, el } 22 . \\
\text { Celera y el PGH oficial discuten su posible colaboración, que no se concreta. }\end{array}$ \\
\hline $\begin{array}{l}14 \text { marzo } \\
2000\end{array}$ & $\begin{array}{l}\text { Declaración del presidente Clinton y de Tony Blair, que invitan a los agentes públicos y privados } \\
\text { de la genómica a transferir los resultados del PGH al dominio público. iBajada inmediata de los } \\
\text { mercados financieros!! } \\
\text { Segundo intento fracasado de colaboración entre Celera y el PGH. La fuente de discrepancia es } \\
\text { la política de liberación de datos. }\end{array}$ \\
\hline $\begin{array}{l}26 \text { de } \\
\text { junio de } \\
2000\end{array}$ & $\begin{array}{l}\text { Se descifra el "libro de la vida", anunciado consecutivamente en China, Japón, Francia, Alemania, } \\
\text { el Reino Unido y Estados Unidos. La presentación pública, realizada en la Casa Blanca, significaba } \\
\text { la culminación de un borrador de secuencia del genoma humano que abarcaba aproximadamente } \\
\text { el } 90 \text { por ciento del mismo. En este acto estaban presentes, junto al presidente de los Estados } \\
\text { Unidos, Bill Clinton, Francis Collins en representación del Proyecto Genoma Humano público y } \\
\text { Craig Venter, presidente de Celera Genomics. }\end{array}$ \\
\hline $\begin{array}{l}\text { Febrero } \\
2001\end{array}$ & $\begin{array}{l}\text { Se publican en Science (número especial de } 16 \text { de febrero) y Nature (número especial de } 15 \text { de } \\
\text { febrero) los resultados. Cada una de estas famosas revistas elige uno de los proyectos: Nature, } \\
\text { la versión del PGH y Science se centra en el borrador de Celera Genomics. El día elegido para } \\
\text { anunciarlo ( } 12 \text { de febrero) es, por cierto, el cumpleaños de Charles Darwin. }\end{array}$ \\
\hline 2002 & Se publica el borrador de secuencia del genoma del ratón (Nature, 5 diciembre 2002) \\
\hline 2003 & $\begin{array}{l}\text { El PGH se considera oficialmente completado coincidiendo con el } 50 \text { aniversario del } \\
\text { descubrimiento de la doble hélice del ADN. }\end{array}$ \\
\hline 2004 & $\begin{array}{l}\text { Se completa la secuencia de los cromosomas humanos } 5,9,10,13 \text { y } 19 \text { y se recalcula la estimación } \\
\text { de genes humanos, de } 20.000 \text { a } 25.000 \text {. }\end{array}$ \\
\hline
\end{tabular}

Selección de eventos relevantes para nuestra investigación en la cronología del PGH. Elaboración propia a partir de múltiples fuentes, especialmente las oficiales.

El arranque oficial del PGH tuvo lugar en 1990, impulsado mayoritariamente por los NIH y otros organismos (ver Tabla 1). Sin embargo, a los pocos años se vio sacudido por la noticia de su bifurcación. En mayo de 1998, el biólogo Craig Venter anunciaba públicamente la fundación de la compañía Celera cuyo principal propósito era, igualmente, secuenciar el genoma humano para el año 2001, adelantándose al proyecto gubernamental en cuatro años; una segunda versión del proyecto que iba a coexistir, y quizás rivalizar, con la primera. Tal pronunciamiento fue el pistoletazo de salida para una carrera que desveló con crudeza las tensiones entre la academia o universidad y la industria (Shreeve, 2004). El movimiento de Venter, que procedía de un proyecto no comercial, a la vez que exteriorizó y representó de forma transparente una síntesis casi perfecta entre negocio y ciencia, generó un número de conflictos y controversias considerable. Una de ellas, fundamental, tuvo que ver con la posesión o propiedad del genoma humano. El consorcio público, formado por equipos de hasta seis países, hizo públicos sus resultados por diferentes medios (Internet, por ejemplo), pero Venter y Celera optaron principalmente por 
distribuciones de tipo patente comercial. Aunque el proyecto arrancara bajo la férrea tutela de Watson, las máquinas para la secuenciación automática del ADN fueron desarrolladas por Venter y su compañía. Es decir, ambas líneas estaban interconectadas desde el principio. En cualquier caso, lo relevante es que la bifurcación y la carrera paralela de investigaciones fueron un rasgo esencial del PGH, que estuvo vinculado durante años a las vías para el reparto y comercialización de los resultados logrados: la postura frente al uso de un tipo u otro de propiedad intelectual/industrial (PI) determinó la evolución de las ramas coexistentes. En el interior de la misma investigación, dos sistemas enfrentados de administración de los resultados (acceso y movilidad de los mismos) convivieron tensamente.

A pesar de que en muchos casos la historia del desciframiento del genoma humano se ha abordado en clave de intrincado juego de personalidades ${ }^{5}$ y ambiciones (Shreeve, 2004: 77-90), cabe al menos entenderlo también como paradigma de los modelos de integración ciencia-mercado que la propiedad intelectual postula y de los conflictos sociales modernos. Durante la primera fase de la investigación, los motivos científicos y de corte desinteresado parecieron abanderar la investigación, proyectando una imagen pública de una empresa entregada al avance voluntario y generoso del conocimiento sin precedentes. Fuera cierto o no, las transformaciones sufridas a lo largo de su corta pero intensa historia, parecieron reflejar un retrato casi opuesto: el de una ciencia empresarial dedicada a generar nichos de mercado para terminar poniendo en bandeja de plata el genoma humano al mejor postor. Aunque estemos caricaturizando la percepción social del PGH, nos interesa subrayar el cambio que pareció sufrir debido a la llegada de nuevos integrantes y a los modelos de investigación y propiedad (acceso y difusión del código genético) asociados a cada uno de ellos.

Al igual que la propiedad de las semillas o los transgénicos, la titularidad de los genes (o de secuencias de $\mathrm{ADNc}$ ) vertebró la conflictividad alrededor del PGH (Pestaña, 1998: 48 y Poste, 1995: 534) propiciando unos patrones de "economización de la naturaleza" (Milanovic, 2011) muy concretos. Numerosos autores han examinado la evolución temporal de la secuenciación del genoma humano poniendo de relieve los titánicos intereses económicos en juego. Las distintas estrategias empresariales han supuesto un papel esencial, pujando y tensando una disputa interminable que ha ido conduciendo y desplazando el curso del proceso investigador. Ambas versiones podrían ilustrar los tipos ideales de las destrezas y habilidades de los distintos "modelos de investigación científico-técnica": una, casi por completo dedicada a solicitar patentes de cualquier gen con posible interés farmacológico para vender posteriormente los derechos a las multinacionales del sector y otra, encaminada a la secuenciación completa de múltiples organismos vivos, aparte del genoma humano, para crear de esta manera una enorme base de datos que sería rentable al cobrar por el acceso a la misma. Son dos modos de comercialización distintos, pero complementarios, dentro del campo de la genómica. La paradoja del caso es que Celera Genomics se iba aprovechando de los resultados intermedios que producía el Consorcio público, pero no a la inversa. El epicentro de este dispositivo gigante y dual de investigación a gran escala fue EEUU, calculándose que el $20 \%$ de las

\footnotetext{
${ }^{5}$ Aunque las cosas, con toda seguridad, no son tan simples y maniqueas como se ha dicho, Celera Genomics y Venter representan idealmente, en este caso, el interés de la empresa privada por el modelo propietario de las patentes. A lo largo de todo el conflicto, Venter ha aparecido ante los ojos de la opinión pública como el representante de los más oscuros y mezquinos intereses egoístas y privatizadores frente a lo que debería ser un patrimonio público y común de la humanidad; en especial tras la polémica dimisión de Watson, debida para algunos, a las visiones encontradas con Venter. Venter sería el "innovador schumpeteriano", un audaz científico-empresario que aparca cómodamente su ética para hacer negocios de más provecho. Frente a él han emergido contrafiguras, erigidas en ídolos morales que anteponen sus principios a la insana avidez por aumentar sus cuentas corrientes. Uno de los nombres propios sería John Sulston, el principal investigador del Sanger Center de Cambridge, que forma parte del consorcio público y que calificó los fines comerciales del genoma humano como "totalmente inmorales y vergonzosos" (Sulston y Ferry, 2002). En otros términos, frente a la figura mediática de Craig Venter, héroe emprendedor ambicioso acusado de encarnar un ávido egoísmo empresarial, se situaría la supuesta moralidad de investigadores como Sulston, europeo y premio Nobel en 2002, que entienden que el "genoma humano: debería ser dominio público por excelencia".
} 
solicitudes de patentes sobre genes humanos provienen de dicho país (Jensen y Murray, 2005: 239). Desde un punto de vista inicial, la secuencia en sí, una interminable lista de letras, tiene poco valor comercial. No obstante, las aplicaciones que se puedan realizar de la misma, orientadas hacia la expansión de la industria farmacéutica o médica, poseen un valor incalculable. El ADN contiene la base del saber terapéutico del futuro: un conocimiento que insinúa negocios lucrativos sin fin para quien detente el control último sobre dicho mapa genético humano. De esta forma, la forma en la que pueda circular ese código (propiedad móvil) determinará el tipo de control sobre lo biológico (y, por ende, sobre lo social).

A pesar de que la aparición de las primeras empresas de biotecnología tiene lugar en los años setenta, no es sino a lo largo de los años noventa cuando se va tejiendo una relación interdependiente entre el sector de la genómica y las biotecnologías, y ciertos segmentos empresariales y mercantiles privados (Pestaña, 1998); una integración compleja y sólida de la investigación científica y la esfera corporativa que desemboca "en el registro masivo de patentes sobre secuencias genéticas, la extensión de las bases de datos protegidas del secreto comercial, la concentración de contratos de acceso exclusivo a los datos genéticos y médicos de determinadas poblaciones, la multiplicación de acuerdos de investigación o de transferencia de materiales que especifican derechos de uso reservado." (Cassier, 2002: 1). Bajo ese proyecto científico-económico florece todo un nuevo universo biotecnológico en tiempo record. Dentro de esa convergencia creciente entre la iniciativa privada y los aisladores de genes asistimos, entonces, a lo que se ha denominado como un enfrentamiento de modelos de investigación: el de "los bienes colectivos" frente al "modelo de privatización" (Heller y Eisenberg, 1998). El campo de la genética, y más particularmente la cartografía de los genes (humanos), ha sido un espacio privilegiado para visualizar el duelo entre la privatización de la investigación y prácticas o propuestas colectivistas, un fenómeno típico de los conflictos de PI. Un paso más allá nos permite afirmar que hemos sido testigos privilegiados de cómo prospera una industria donde hace poco no existía, de cómo cristaliza y madura todo un complejo de investigación y comercialización gracias a la articulación de avances científicos y un régimen económico-jurídico pujante (Mendiola, 2006: 242-248). La posibilidad (y realidad) de patentar los genes aislados en laboratorios ha construido todo un macroespacio de operaciones tecnológicas y económicas donde se articula lo científico y lo mercantil ${ }^{6}$ con un nivel de revalorización desconocido hasta la fecha (Pestaña, 1998: 45). A lo que hay que sumar una serie de traslaciones de lo público a lo privado, desde la investigación fundamentalmente académica a la empresa tecnológica moderna, que ha bebido y se ha alimentado de la primera (Commoner, 1998: 24). Las empresas biotecnológicas constituyen un híbrido entre la investigación clásica pura (como tipo ideal) y las empresas tradicionales (como tipo ideal también). Se ubican dentro de una línea que tendría, a un lado, los laboratorios académicos y, a otro, los laboratorios farmacéuticos, resultando, de la agitada mezcla de las características de ambos casos, ciencia y mercado, investigación y beneficio.

Este eje de modelos de investigación en función del nivel de imbricación entre lo económico y la investigación no sólo representa un esquema teórico, sino también una dinámica temporal; un proceso histórico reciente por el que ha transitado la investigación biomédica en algunos lugares (Heller y Eisenberg, 1998: 698) y que constituye lo que se ha dado en etiquetar como "postfordismo biológico" (Mendiola, 2006: 248) o "postfordismo biotecnológico". Desde 1980, casi todas las leyes norteamericanas de regulación del campo biotecnológico, farmacéutico o médico en materia de patentes han dislocado la cultura de la investigación científica conocida ${ }^{6}$, fusionando economía y ciencia, formando híbridos como la figura de los "ingenieros genéticos" (Durán y Riechmann, 1998: 17). De ello se deriva una colección de consecuencias en las que no vamos a sumergirnos pero que dejan constancia del desplazamiento producido en la práctica científica,

\footnotetext{
${ }^{6}$ Por ejemplo, la famosa Bayh-Dole Act (Rai, 2002: 19 y Mowery y Ziedonis, 2002). Se incluye también la creación de las famosas OTRIs (Oficinas de Transferencia de la Investigación), auténticas pasarelas y conectores entre el espacio académico y el empresarial (Pestaña, 1998: 39); justo el momento en el que las grandes empresas de biotecnología actuales tomaron el centro del nicho o panorama investigador mundial.
} 
debido a la implementación de políticas de propiedad intelectual cada vez más intensas (que modulan la movilidad de dicha práctica en un sentido general). Por supuesto no estamos afirmando que la interrelación entre innovación (tecno)científica y empresa no existiera anteriormente (ver, por ejemplo, Latour, 1995 o Noble, 1987) sino el cambio cualitativo producido por la masividad legal (hiperreglamentación), los nuevos objetos (genética, biotecnología, etc.), los modelos de trabajo (orientados solo a la obtención de la patente) y los condicionamientos espaciales (el laboratorio pasa a incorporarse físicamente al espacio empresarial). La fusión es ahora mucho más perfecta, sin costuras ni remiendos.

La genómica se ha convertido (junto con el software) en el arquetipo de un tipo de investigación científica y tecnológica cuya eficiencia aumenta con la descentralización y la distribución en una red de microcentros. Solo la cooperación sinérgica y difusa (móvil) que permita la convergencia constructiva de resultados parciales, datos intermedios y pequeños avances, puede facilitar la consecución de metas complejas que requieren mucho manejo y circulación de información. Esto es, la gestión del conocimiento tecnocientífico parece que tiende a organizarse de modo más eficiente en redes cooperativas, precisamente en las áreas donde más conflictiva se vuelve la propiedad intelectual. No constituye una pura cuestión de topología y velocidad sino de administración eficaz de la investigación y la labor científica cuando se desarrollan bienes inmateriales. Presenciamos, entonces, diferentes modelos de producción y distribución de bienes colectivos y/o públicos dentro de una misma disciplina científica (e incluso dentro de un mismo proyecto de investigación). Mientras las patentes representan el elemento central de la apropiación privada en la investigación en genética (y su distribución fluida mercantil), ciertos planes de desarrollo biotecnológico descentralizado y reticular promueven instrumentos de protección o colectivización de los recursos producidos. ${ }^{7}$

Insistimos en que comúnmente los sistemas de investigación científica a gran escala actúan median- te aportaciones locales y desperdigadas, formando un agregado de "redes socio-técnicas" (Latour, 2005). En el caso del PGH, cada participante ejerce su papel con un grado de descentralización alto pero generando una carta genética común. Ello ha favorecido el aumento de la eficiencia organizativa (como en el caso del PGH), de manera que numerosos consorcios europeos han experimentado con diversos regímenes de distribución de la propiedad intelectual de los datos obtenidos de manera cooperativa. Estas múltiples formas de propiedad comunitaria corren paralelas a los modos de ensamblar las investigaciones de cada laboratorio y su autonomía o movilidad relativa. Es decir, existe un nexo apreciable entre la estructura y geometría organizativa de las investigaciones científico-técnicas (la movilización de sus resultados) y los tipos de propiedad intelectual o modos de regulación económica de los bienes intelectuales.

En última instancia, la "mercantilización de la vida" (desde la materia biológica común a la vida humana en concreto) tiene que ver con la "compatibilidad o incompatibilidad entre seres vivos y mercados capitalistas" (Duran y Riechmann, 1998: 13 y Waldby y Mitchell, 2006). La convergencia entre el intercambio mercantil y el par biotecnología-genómica en un escenario global se concreta y garantiza mediante una fórmula legal propietaria (las patentes) que, como auténtico dispositivo biopolítico ejerce de maestro de ceremonias para tal enlace. Cuando se "consideró la vida como invento" (Shiva, 2003: 7), las patentes permitieron engrasar la máquina para el intercambio global generalizado otorgando un grado de movilidad a las entidades tecnocientíficas desconocido hasta la fecha (para este punto, recomiendo la descripción histórica en el caso de EEUU que realiza David Noble, 1987). La "naturaleza transformada" es la nueva invención comercial que, mercantilizada eficazmente a través de las convenciones que la PI suministra, surca los nuevos mercados globales. Manipular la materia viva hasta su constitución más íntima dibuja una situación históricamente única y nueva. Las posibilidades comerciales del conoci-

\footnotetext{
${ }^{7}$ Por ejemplo: "El proyecto BIOS impulsa el código abierto en la investigación biotecnológica" http://elpais.com/ diario/2006/04/20/ciberpais/1145500526_850215.html (El País, 20 Abril 2006) o un test genético con licencias libres: "The renegade gene test", http:/www.nature.com/news/2010/101014/full/news.2010.540.html (Nature, 10 Octubre 2010).
} 
miento derivado del genoma humano abren un nuevo campo social y económico. Tal novedad acarrea dos hechos reseñables: i) el primero, la indisociable realidad económica asociada a la innovación técnica, una fusión perfecta de mercantilización, vía propiedad intelectual con ciertos modelos de investigación y ii) el segundo, un conjunto de conflictos sociales cada vez más intensos que comienzan a cobrar interés en las ciencias sociales de las últimas décadas (Durán y Riechmann, 1998: 11) y que toman la forma de "guerras de ciencia" (Ross, 1996) o "guerras de patentes (patent wars)" (Warshofsky, 1994) pero que pueden interpretarse también desde la gestión y acceso a objetos de conocimiento (que han sido mercantilizados).

\section{INNOVACIÓN COMO DISCURSO BIOPOLÍTICO}

"We worship at the church of innovation. We take it as an a priori good. [Adoramos la religión de la innovación. La tomamos como un bien a priori." (Boyle, 2003: 14)

Varios elementos nos llaman la atención respecto a las justificaciones dadas a favor de la patentabilidad de secuencias genéticas y del proceso de explotación comercial de las mismas por parte de oficinas de patentes y propietarios de genes. El paso del ADN como "molécula de vida" (esencia biológica compartida) al ADN como información patentable o fórmula química (invenciones humanas apropiables) requiere de operaciones retóricas y semánticas que orientan la controversia y resuelven parte de los conflictos que se plantean. Son, para los estudios sociales de la ciencia y la tecnología, modos de cerrar y zanjar controversias y, en la sociología económica, métodos de construcción social de propiedad económica. En los principales elementos retóricos o metafóricos que se plantean en las controversias, pueden encontrarse determinadas suposiciones tácitas que abogan por líneas o posturas concretas, y que condicionan en gran parte el resultado del conflicto. Dicho de otra manera, en las situaciones de debate enfrentado que caracterizan los antagonismos de propiedad intelectual e industrial subyacen implícitamente toda una serie de rutinas discursivas o modalidades epistémicas que van construyendo y definiendo la realidad social, modulando la controversia e introduciendo auténticas teorías sociales (y políticas) bajo el formato de supuestos argumentos técnicos.

Llegados a este punto, merece comentar que, dentro de esa indefinición y ambigüedad manifiesta de lo biopolítico que, a la vez, está en todas partes o es singularmente específico de nuestra época, nuestra labor no alcanza o se completa solo con describir algunos dispositivos que encajan en la propuesta foucaultiana. Merece la pena, al más puro estilo genealógico, rastrear los marcos o imaginarios epistémicos donde esos dispositivos tienen cabida o cobran sentido. Entendemos que en el caso de las patentes, en tanto títulos que regulan la movilidad de los objetos tecnocientíficos, existen soterrados (y asomados) fundamentos ideológicos o esquemas culturales que funcionan como a prioris de la discusión, como grado cero de la racionalidad política. En este caso, la apropiación comercial de los genes humanos pivota sobre el paradigma de los incentivos (acicate de la investigación) y el estímulo a la innovación como legitimación racional a la administración privada de los bienes tecnocientíficos (medicamentos, semillas, genes, etc.). El sustento del vínculo entre el campo económico-jurídico y el espacio tecnocientífico es un discurso cultural (y biopolítico) que gestiona la incertidumbre y el futuro de la población en términos de progreso técnico neutro y positivo. En nuestro caso, la extensión de las patentes como modo principal de gestión de genes, semillas o materia viva y, más en concreto, en el caso del PGH, pivotó sobre la concepción utilitarista de las mismas, dando por supuesto que avalaban la innovación tecnocientífica y certificando crecimiento y bienestar. Esa apelación a la innovación como marco general de progreso social se ha mantenido en los últimos años como apoyo teórico y político generalizado.

En los últimos tiempos la palabra "Innovación" ha alcanzado una posición privilegiada, tanto en el campo de la opinión pública como de los discursos sociales, políticos y mediáticos. En apenas un par de décadas, la idea de Innovación ${ }^{8}$ se ha convertido en un cliché sociológico, en un remedio y cura milagrosa a cualquier tipo de crisis (salvación nacional y empresarial) y en una palabra recurrente en la vida social. Según el Oxford English Dictionary, 
la palabra "Innovation" se empezó a usar en 1553 como "introducción de novedades" y se la recuerda hasta dentro de alguna obra de Shakespeare. ${ }^{9}$ Sin embargo, no es hasta 1930-1940 que Schumpeter la rescata y resucita para las Ciencias Sociales, conectando innovación con la figura del emprendedor y con ciclos de negocio en el capitalismo (innovación y emprendimiento, serán para este economista, los motores del capitalismo moderno). Según Schumpeter, los "gifted pioneers" (emprendedores) consiguen asociar de manera productiva ciencia, tecnología y economía de mercado, conexionando esos campos dispersos. Frente al empresario capitalista weberiano, intramundano, disciplinado y sacrificado por su profesión, Schumpeter propone un sujeto del cambio económico muy distinto (Swedberg, 1991). No estaríamos ante un asceta calvinista sino ante un individuo en movimiento perpetuo de decisión arriesgada, de "creación destructiva" y de riesgo emprendido.

Posteriormente, la retórica de la Innovación hay que encontrarla en el espacio empresarial, más en concreto en la rama de la industria y la propiedad industrial al calor del nacimiento de las grandes corporaciones a principios del siglo XX (Noble, 1987). Por ejemplo con figuras históricas como la de Thomas Edison que personificó la simbiosis entre inventos técnicos y productos comerciales y, a partir del cuál, ya no es posible pensar la invención técnica al margen de su venta y mercadeo. La innovación, desde entonces, significa la aplicación socioeconómica del invento, o la proyección mercantil, rentable y útil de una idea original. A lo largo de todo el siglo $\mathrm{XX}$, este paradigma se va afianzando, entretejiendo lazos del campo científico técnico como el económico y consolidando el paso que se ha denominado "del inventor solitario a la gran empresa" (Noble, 1987: 129). Aún así, el concepto asumió su lugar de "palabra semi-dormida" hasta la década de los 1980-1990. Esta posición secundaria (stand-by) del término, se rompió hace un par de décadas cuando la innovación cobró un protagonismo inusitado gracias al último ciclo de tecnologías digitales e infor- máticas y al cambio de modelo económico. Ahora mismo, "Innovación" es un tópico recurrente en la literatura empresarial y económica y en discursos políticos y sociales que opera como base epistemológica e ideológica que todo lo permea del ciclo biopolítico actual.

Sin embargo, certificar el crecimiento cuantitativo de la presencia pública de la innovación (Klein, 2001: 3-4) no nos indica completamente su significado y sentido social. Más en concreto, existen modelos de discurso que históricamente han ido alternándose y este relevo es sustancial para nuestra investigación: A) el discurso descriptivo (el más popular): aquel que se centra en el lanzamiento de nuevos procesos o productos de carácter tecnocientífico y B) el discurso prescriptivo o normativo (el más reciente): aquel que se formula como imploración o mandato y destila una confianza extrema en el progreso tecnológico como medida o estrategia. La Innovación descriptiva es un canto a la novedad generalizada que lleva fraguándose todo el siglo XX $\mathrm{y}$ donde podemos encontrar trazos del viejo determinismo tecnológico y de la fe en el progreso (Nisbet, 1980). No obstante, no deja de ser un fiel reflejo de la evolución humana y de su tendencia práctica a resolver cuestiones de cierta forma. Más interesante resulta mirar con lupa la Innovación prescriptiva, enunciada como imperativo, con cierto carácter normativo en sus apelaciones al "new and novel". Hablamos ahora no tanto de una sucesión de cachivaches y aparatos sino de una actividad orientada (impelida) normativamente hacia otros lugares y conectada con otros términos: aplicabilidad, desarrollo industrial, emprendizaje, negocio, etc. En los años 1980-1990, la innovación prescriptiva llegó a volverse un discurso "estridente, urgente y evangélico" (Klein, 2001: 6). Asistimos entonces a una fase en la que cualquier referencia al corpus tecnocientífico y a las medidas de intervención económica se implora y conmina a organizaciones y personas a ser innovadores. Cambia también el tono (y el apellido) de las políticas públicas y científicas, que pasarán a

\footnotetext{
${ }^{8}$ Etimología: Del latín innovare que significa acto o efecto de renovar o introducir una novedad.

9 "To face the garment of rebellion With some fine color that may please the eye of fickle changelings and poor discontents. Which gape and rub the elbow at the news Of hurly-burly innovation." (William Shakespeare, King Henry, in Henry IV, Part 1, act 5, sc. 1, 1. 74-6, aprox. 1599).
} 
llamarse: políticas de innovación, proyectos $\mathrm{I}+\mathrm{D}+\mathrm{i}$, etc. Cambia hasta el tono empresarial: "Innovate or die" ó "Don't wait to innovate" $10 \mathrm{y}$, como corolario, el eslogan publicitario de la década de los 1990 fue: "Don't imitate, innovate" (Calvin Klein, 1999).

En general la innovación prescriptiva está orientada a individuos, organizaciones y países formando parte de una cierta "retórica política" cuya discursividad toca de lleno las actitudes frente al cambio y al cambio tecnológico en particular. De esta forma, la innovación se acepta como un bien positivo sin cuestionamiento a priori generando una auténtica "Sociedad de la Innovación". No podemos evitar incluir aquí el reconocimiento de una de las biblias del catecismo neoliberalismo que reconocía la situación y lo expresaba así: "Innovation has become the industrial religion of the late 20th century. Business sees it as the key to increasing profits and market share. Goverments automatically reach for it when trying to fix the economy. Around the world, the rethoric of innovation has replaced the post-war language of welfare economics. It is the new technology that unites the left and the right of politics." (The Economist, 'Survey on Innovation in Industry', 17 Marzo 1999).

Este eje discursivo propulsa muchas de las argumentaciones y retóricas que proyectan e impulsan al nuevo régimen económico global (neoliberalismo). ${ }^{11}$ Solo tras la estela de ciertas crisis y nacientes ciclos económicos, lo innovador ha conquistado el carácter y la naturaleza de solución o respuesta natural y necesaria (es un discurso históricamente situado). Pero los discursos no solo describen o hablan de las cosas sino que también hacen cosas (son materiales). La innovación comparte con otros esquemas retóricos (management, competitividad, emprendizaje, etc.) la labor de racionalización política del orden global (Rose, 1996 y Sennett, 2006). Desde los años setenta, la reconversión y reconfiguración del modelo productivo y de los paradigmas económicos han tenido su correlato en el campo de la financiación tecnocientífica (auténticos movimientos tectónicos en el orden social mundializado).

Dentro de esta historia apresurada cabe hacer un inciso ya nuestro enfoque no es del todo original. La relación entre leyes de patentes y revolución industrial ha sido, sin duda, bien estudiada, y parecen existir correlaciones interesantes. Entre 1765 y 1789, el parlamento inglés aprobó una serie de leyes estrictas que impedían la exportación de máquinas nuevas o de planos o modelos de las mismas. Los trabajadores cualificados que trabajan en las máquinas no podían salir de Inglaterra para asegurarse de que Inglaterra seguía siendo una potencia industrial. La tesis de Macleod (1988 y 2009), secundada por otros trabajos historiográficos, es precisamente que durante cierto periodo histórico (1660-1800) la transformación del sistema de patentes (en Inglaterra) desde mero instrumento real de patronazgo hasta el de competitividad comercial sirvió de guía al desarrollo y formación del capitalismo industrial en dicho país. Idea que tendría sentido agregar al resto de análisis historicos que buscan dar cuenta de la hegemonía británica desde otras ópticas. No se trata de valorar moralmente si las patentes son buenas o malas (ver, en ese caso VVAA, 2005) sino de analizar las irreversibilidades contenidas en su uso y aplicación, entendiendo su funcionamiento político como gestor del capital tecnocientífico en ciertos periodos. La organización racional de las patentes (que habilitaba la movilidad del capital tecnológico) no fue posterior al despegue industrial sino previo o, como mucho, simultáneo. Así que nuestras intuiciones se encuentran amparadas por este tipo de aproximaciones donde en vez de interpretar el desarrollo tecnológico a la par que el crecimiento económico como líneas disociadas, se comprende el cambio de ciclo como resultado del proceso de agregación del espacio tecnocientífico con ciertos segmentos industriales a través de las patentes. Para MacLeod, di-

\footnotetext{
${ }^{10}$ Ver:Rosabeth Moss Kanter, “Don’t Wait : o Innovate,” Sales \& Marketing Management, February 1997. pp. 22-24.

${ }^{11}$ Un caso empírico es el Ej. Libro Verde de la Innovación (Unión Europea, 1995) que desgrana frases tales como: "La innovación es indispensable para la viabilidad y el éxito de la economía moderna." (LVI, pág. 4), "La innovación está en el núcleo del espíritu empresarial: prácticamente toda nueva empresa nace de una actuación innovadora, como míni-mo respecto a sus competidores." (LVI, pág. 17), "La competencia entre empresas independientes es la primera fuerza motriz de la innovación." (LVI, pág. 23), etc.
} 
chas propiedades temporales no son la consecuencia esperada de un boom industrial sino su misma condición de posibilidad, no existiendo un capitalismo industrial efectivo sin estas herramientas previas de apropiación y movilidad del saber técnico (2009). Convertirse en la "primera nación industrial" afirma MacLeod requirió tomarse en serio la circulación y aplicación de las invenciones técnicas, auténtica exigencia para la explotación empresarial de la máquina de vapor ${ }^{12}$ y para el arranque de las industrias textiles (2009: 37-38). El cambio tecnológico no produjo una transformación unidireccional del modelo productivo hasta que no se perfiló y pulió un sistema adecuado para la difusión del mismo. Si la regulación de la movilidad de los objetos técnicos fue una precondición para la forja de un capitalismo de corte industrial y fabril, vemos su paralelismo actualmente con la consolidación de ciertos sectores de investigación tecnocientífica (biotecnologías, genómica, etc.) sobresalientes en la era global pero impensables sin dispositivos de administración, posesión y circulación adecuados.

Ahora bien, al lector/a le asaltará la duda de por qué este excurso sobre la innovación cuando los objetos genéticos no lo son en cuanto tal. Ha existido un proceso de asimilación del descubrimiento genético a la innovación científica, nada evidente, que no se ha explicitado hasta ahora. La patentización de la genética y las biotecnologías ha tenido que ser escoltada por complicadas operaciones semánticas y maniobras lingüísticas, insertadas en los textos jurídicos para garantizar la extensión de los derechos de PI. La introducción de retorcidos términos y la creación ad hoc de conceptos ambiguos (lo "esencialmente biológico"13, la existencia de "contribución técnica, etc.) han permitido la apropiación de lo que escapaba a los marcos jurídicos, completando el proceso de cercamiento de los bienes intelectuales o biológicos. El despliegue de la Propiedad Intelectual sobre "lo vivo" es concurrente con la disolución de la distinción entre "descubrimientos" e "invenciones", una vieja dicotomía cada vez menos válida y precisa que ha requerido de construcciones metafóricas operativas legalmente.

\section{BIOPOLÍTICA Y CONTROL SOCIOTÉCNICO (MOVILIDAD DE LOS OBJETOS TECNOCIENTÍFICOS)}

El capitalismo nació industrial y se erigió sobre la figura de una máquina especial: el reloj (Sibilia, 2009: 17). Dicho dispositivo permitía la sincronización mundial de actividades productivas y de las tareas humanas al servicio del industrialismo incipiente. En ese sentido, podemos identificar a este objeto como un dispositivo biopolítico muy refinado que regulaba los intercambios mercantiles, ponía en hora a las diferentes poblaciones y coordinaba el desarrollo del Estado moderno. Sin embargo, el capitalismo globalizado y postindustrial ha dislocado parte de los marcos nacionales y locales de producción y consumo requiriendo un dinamismo y movilidad diferente al presentado por el reloj (Lash y Urry, 1987). La preeminencia del capital financiero y los flujos de dinero y activos que recorren el planeta se han impuesto a las inmóviles fábricas decimonónicas. Ahora que el sistema nervioso digital de la tierra está formado por flujos o corrientes de intercambios son necesarios mecanismos que regulen la circulación de objetos (o redes) y, de paso, no solo los hagan moverse sino también los valoricen en ese mismo proceso modulando su producción y su consumo. Frente a la noción de propiedad clásica, pareciera que la propuesta de "acceso" va sustituyendo a la anterior. Pero este acceso (Rifkin, 2000) no es sino la versión actualizada de la propiedad clásica,

${ }^{12}$ De hecho el invento de James Watt estuvo paralizado un tiempo debido a infringimiento de patentes (MacLeod, 2009: 38).

${ }^{13}$ El caso de la Directiva 98/44/CE de Protección Legal de las Invenciones Biotecnológicas (Parlamento Europeo y Consejo, 6 de julio de 1998) es relevante al incorporar el término de proceso "esencialmente biológico", una definición ad hoc que permite insertar las patentes sobre vida orgánica. Sólo se excluyen los procesos "esencialmente biológicos" de la apropiación pero dando una definición tan pura que no existe lo "esencialmente biológico" porque siempre hay intervención humana en la elaboración, aislamiento u obtención de ciertas sustancias y objetos. Si hay "contribución técnica" hay posibilidad de patente: "Se entenderá por «contribución técnica» una contribución al estado de la técnica en un campo tecnológico que no sea evidente para un experto en la materia.” (98/44/CE, Artículo 2, pág. 21). 
convertida ahora en propiedad intelectual móvil. ${ }^{14}$ Gracias a la organización política de la tecnociencia y a la administración racional de las innovaciones científicas y tecnológicas que obedecen a precisas reglas de posesión y acceso, el régimen biopolítico global sobrevive. La superación de las sociedades disciplinarias pasa por estas nuevas modalidades y su manejo de sujetos/objetos que se dispersan aceleradamente y por dispositivos de poder cuya lógica resulta algo diferente ("gubernamentalidad digital"). La gestión móvil (que hace transitar los espacios) de la tecnociencia o del conocimiento no es, como juicio moral, ni buena ni mala, pero tampoco neutral. Provoca una serie de consecuencias irreversibles cuyos resultados materiales prescriben los ordenamientos sociales (la distribución de bienes intelectuales o técnicos en el capitalismo cognitivo). En ese sentido podemos interpretar estos mecanismos como elementos biopolíticos que organizan la vida (la supervivencia médica, la constitución biológica común de la especie o el acceso a recursos agroalimentarios). Lo interesante es que, en este caso, la movilidad de una patente produce una regulación positiva (no moralmente buena) ya que reglamenta el acceso y el uso de ciertos objetos: su uso y existencia social.

Los estudios de Foucault demostraron que los mecanismos de poder y saber de la modernidad industrial ganaron en eficacia y sutileza a sus predecesores medievales y clásicos superando las rudas violencias por controles sibilinos y automáticos. La arquitectura panóptica o la técnica de la confesión se depuraron promoviendo una autovigilancia generalizada, la normalización cotidiana de sujetos y la gestión demográfica o psicológica de la vida (Foucault, 1996). Los dispositivos de biopoder de la sociedad industrial confeccionaron sujetos dóciles para la vida laboral y fabril (engranajes de la producción fabril): cuerpos sumisos pero productivos. En la sociedad industrial las disciplinas operaban sobre el cuerpo mismo, sobre los sujetos y las normas de su vida. En las sociedades globales de un capitalismo avanzado (financiero, de consumo, simbólico, cognitivo, etc.), estos poderes operan también a través de los objetos y sus hibridaciones. Las vidas bajo el capitalismo digital (cuya mercantilización generalizada ha traspasado el ámbito de los cuerpos) requieren de complejas fórmulas de consumo masivo con objetos que circulan alrededor de nuestras vidas.

La biopolítica contemporánea, si es que queremos indagar qué formas contiene o adopta, está emparentada, entre otras cosas (no solo), con la construcción de mercancías mundializadas y con la gestión de la tecnociencia y los objetos simbólicos (formas sociotécnicas de control). A la pregunta por la validez externa (generalización, extrapolación) de la propuesta foucaultiana debemos indicar que, hoy por hoy, la biopolítica tiene mucho que ver con la ordenación y tutela de la movilidad de sujetos y objetos. Tiene más sentido inspeccionar las variantes históricas, contemporáneas, de imbricación entre racionalidad política y poblaciones que obsesionarse con definiciones atemporales, esencialistas y limitantes. No nos importa tanto profundizar en una ontología de la biopolítica como en historizar las formas biopolíticas actuales para desentrañar los modos particulares de la fase postfordista (aquí los operaístas como Lazzarato han trabajado bastante, 2005) o incluso post-postfordista. Si la nueva columna vertebral del modelo socioeconómico tiene que ver con la producción y circulación de información y saber técnico, las intervenciones y enunciaciones que apuntan a garantizar su movilidad tendrán que apelar a justificaciones ideológicas que apuntalen

${ }^{14}$ Frente a la acumulación física, ahora renace el acceso regulado. Y dicho acceso, que no deja de ser un dispositivo biopolítico, requiere de mecanismos de reglamentación (prescripción y prohibición) que lo definan: la propiedad intelectual: "Hay quienes detectan una cierta pulverización de la propiedad privada, otrora sólida y afirmada en los bienes materiales. En un régimen que se yuxtapone al de la propiedad de los bienes, estaría ganando fuerza una noción bastante más volátil y flexible: el acceso... [...] Lo que cuenta cada vez más no es tanto la posesión de los bienes en un sentido tradicional, sino la capacidad de acceder a su utilización como servicios. Así, surgen soluciones como el leasing, que permite esquivar la obsolescencia constante de los productos como los automóviles y las computadoras, convirtiéndolos en servicios a los cuales los interesados pueden acceder. En vez de comprar el producto específico y concreto, el consumidor adquiere el derecho a usar un bien siempre actualizado, mediante el pago de una cuota mensual a las instituciones financieras que operan como intermediarias." (Sibilia, 2008: 20 y 21). O también: "La propiedad es una institución demasiado lenta para ajustarse a la nueva velocidad de nuestra cultura” (Rifkin, 2000, p. 5). 
el nuevo régimen (innovación como cambio social favorito e incuestionado). Para ciertos teóricos, la construcción de un sistema basado en la explotación de fuerza de trabajo intelectual (que vende su capacidad para producir o procesar información) genera una sociedad completa que produce valor (la "fábrica difusa") y acarrea también otros mecanismos de valorización y movilización tanto de la nueva fuerza de trabajo como de sus productos. La consecuencia inmediata, es la deslocalización y desterritorizalición de la fuerza de trabajo que se vuelve móvil, tanto ella (migraciones) como simultáneamente sus productos (lo que aquí tratamos). De esta manera, el mercado, ahora ya global, se vuelve un articulador de lo social gracias al gobierno de la movilidad (mediante propiedades temporales) de ciertos objetos valiosos (el conocimiento sobre lo viviente).

A la vista de estos casos, es necesario, por tanto, superar tanto la vieja noción de poder (como instancia unidireccional y negativa para reprimir o prohibir) como una simple biopolítica de los cuerpos (disciplinamiento directo de los sujetos) para comprender cómo esas redes de propiedad de objetos o circuitos de comercio inmaterial internacional encarnan un complejo juego de fuerzas donde se construye y valoriza el hecho sociotécnico. Estos vectores productivos que atraviesan instituciones y agentes clásicos de manera deslocalizada son la forma actualizada en la que se interprenetran economía y tecnociencia, ya indistinguibles. La vieja articulación foucaultiana entre saberes y poderes toma cuerpo ahora a través de tácticas de comercio internacional basadas en el campo de la innovación. El saber apropiable, el cuerpo mercantil, las ciencias aplicadas transferidas, etc. son los nuevos objetos del capitalismo global donde la innovación como dispositivo biopolítico (discursivo, simbólico, legitimador) permite el despliegue de estos mercados globales.

Resulta fundamental apuntar que la elección del caso quizás pueda llegar a confundir en una lectura apresurada. No estamos hablando de biopolítica (o no solo) por el hecho de que las patentes tengan que ver con la genética $y$, por ende con la vida humana (genoma humano). También ocurre cuando se tratan los regímenes de propiedad intelectual sobre semillas, transgénicos o software. Estamos hablando de biopolítica porque apuntamos de lleno al núcleo duro del control social contemporáneo (sobre el conocimiento técnico), a la forma en la que se articulan política y vida mediante complejos procedimientos de gestión económica y orden jurídico-político. Manipular y coleccionar organismos vivos no es una actividad nueva pero sí su materialización contemporánea donde dicha actividad se regula legalmente y forma parte del corpus político-normativo. La intervención sobre lo viviente y la gestión económica de lo vivo son dos caras de la misma moneda que se retroalimentan, no pudiendo darse una sin la otra. Las biotecnologías y la genómica dependen de la existencia de "recursos biológicos explotables" (Milanovic, 2011), sean vegetales, animales o específicamente humanos, y, a la vez, estas posibilitan una capacidad cada vez mayor de ordenar lo social y intervenir y fiscalizar políticamente la vida.

El control de la distribución de los recursos biológicos (de orígenes vegetales, animales o humanos) se ha acompañado efectivamente de un marco jurídico-económico de prácticas cada vez más precisas y funcionales e indispensables pero cuya forma histórica también ha sido cambiante ${ }^{15}$, con momentos de expansión o fases de crecimiento y otros de estancamiento o retroceso. Brevemente para el caso de las patentes:

Pero una genealogía atenta de dichas técnicas o procedimientos de gestión del conocimiento sociotécnico aplicado (que las limitan y las movilizan) también muestra que han evolucionado históricamente de menores o a mayores cotas de movilización de los recursos, transformándose conceptualmente y adaptándose al curso de los tiempos:

\footnotetext{
${ }^{15}$ Buscando "un análisis en el que lo biológico y lo histórico no se sucederían sino que se ligarían con arreglo a una complejidad creciente conformada al desarrollo de las tecnologías modernas de poder, que toman como blanco suyo la vida." (Foucault, 1995: 184)..
} 
Tabla 2: Evolución histórica de las patentes (en Europa fundamentalmente y hasta 1995)

\begin{tabular}{|c|c|}
\hline $1443-1474$ & Primeras patentes y Ordenanza de patentes veneciana (1474). \\
\hline 1624 & Statute of Monopolies o Monopoly Act (Inglaterra). \\
\hline 1769 & $\begin{array}{l}\text { James Watt patenta un "condensador conectado a un cilindro con una válvula" al reparar la } \\
\text { máquina de vapor de Newcomen y Calley (1712) desarrollada, a su vez, sobre una patente de } \\
\text { una olla a presión de Savery (1698) }\end{array}$ \\
\hline 1790 & Primera Ley americana de Patentes tras introducirlas en la Constitución de 1787. \\
\hline 1791 & Primera Ley francesa de Patentes. \\
\hline 1830 & El telégrafo pone de moda las patentes en EEUU. \\
\hline 1877 & Alemania aprueba una ley de patentes con "examen obligatorio". \\
\hline $1880-1882$ & Periodo durante el cual la mayoría de países europeos elabora sus leyes de patentes. \\
\hline 1883 & Convención de París para la protección de la Propiedad Industrial. \\
\hline 1885 & Ley de patentes japonesa tras un primer intento fallido en 1871 . \\
\hline 1947 & Acuerdo de La Haya para la creación del Instituto Internacional de la Patente de La Haya. \\
\hline 1963 & Convención de Estrasburgo. \\
\hline 1970 & Firma del PCT (Patent Cooperation Treaty). \\
\hline 1973 & $\begin{array}{l}\text { Convención de Munich y firma de la Convención Europea de Patentes o EPC (European Patent } \\
\text { Convention) por parte de } 16 \text { de los } 21 \text { países firmantes. }\end{array}$ \\
\hline 1975 & $\begin{array}{l}\text { Conferencia de Luxemburgo sobre la patente comunitaria y firma de la por parte de } 9 \text { estados } \\
\text { miembros de la CEE. }\end{array}$ \\
\hline 1978 & Primera solicitud de patente europea (1 de junio). Entrada en vigor del PCT. \\
\hline 1980 & Concesión de las primeras patentes europeas y más de 10.000 solicitudes. \\
\hline 1985 & Segunda Conferencia de Luxemburgo sobre la patente comunitaria. \\
\hline 1989 & Tercera Conferencia de Luxemburgo sobre la patente comunitaria. \\
\hline 1992 & Concedida la patente 200.000 en Europa y publicada la solicitud 500.000. \\
\hline 1995 & Concedida la patente número 300.000 . \\
\hline
\end{tabular}

Elaboración propia utilizando varias fuentes (Fundamentalmente la Oficina de Patentes Europea) 
Tabla3: Evolución conceptual de las patentes.

\begin{tabular}{|c|}
\hline $\begin{array}{c}\text { Concesiones y privilegios monárquicos } \\
\text { (movilidad restringida) } \\
\downarrow \\
\text { Secretos mercantiles para fabricar y co- } \\
\text { merciar (movilidad restringida). } \\
\downarrow \\
\text { Monopolios sobre invenciones útiles } \\
\text { (movilidad restringida). } \\
\downarrow \\
\text { Propiedad de los descubridores (registrado- } \\
\text { res): el inventor solitario (movilidad limitada). } \\
\downarrow \\
\text { Propiedades temporales vendibles: la gran em- } \\
\text { presa como inventora (movilidad alta, nacional). } \\
\downarrow \\
\text { Internacionalización de las patentes, tra- } \\
\text { tados de reconocimiento supranacional, } \\
\text { Extensión ilimitada a lo orgánico. } \\
\text { (movilidad extrema, global) }\end{array}$ \\
\hline
\end{tabular}

Elaboración propia utilizando varias fuentes.

\section{CONCLUSIONES}

A lo largo de este artículo, hemos planteado la necesidad perentoria de verle el rostro y detectar los rastros de la biopolítica del capitalismo global, intentando superar las teorizaciones excesivamente mistificantes y omniabarcadoras de algunas perspectivas cuyo formato discursivo intelectual autorreferente acaba por perder potencia sociológica (desde un ensanchamiento difuso a un reduccionismo esencialista). Resulta fundamental contextualizar las aportaciones foucaultianas para aprehender la historicidad de la biopolítica contemporánea, que no tiene porque ser un calco o plagio exacto de la que describe el filósofo francés para el siglo XVIII. Asimismo, el intento de cruzar la mirada biopolítica con el paradigma de la movilidad nos ha permitido interpretar un cierto caso (las patentes sobre genes humanos) desde una óptica algo diferente. No buscamos moralizar la crítica a la mercantilización del cuerpo humano (que puede ser pertinente) ni estudiar los efectos sociales de la apropiación de secuencias genéticas. Más bien, proponemos estudiar las patentes como dispositivos biopolíticos que regulan la movilidad de objetos técnicos y científicos (bienes intelectuales), definiendo su acceso y uso y garantizando la circulación de los mismos en los mercados globalizados (a la vez que definiendo modelos de investigación). Movilidad no tanto como cinética (desplazamiento en el espacio), que también, sino como accesibilidad y reticularidad (contacto con otros objetos y sujetos). Dichos títulos de propiedad temporal, activan la ubicación de ciertos elementos (genes, medicamentos, semillas, etc.), trasladándolos de lo público a lo privado (y viceversa). Su movilidad, modulada por la dinámica patentista opera como un mecanismo biopolítico de gestión de la vida (y de la tecnociencia) soportado por un entramado discursivo e ideológico complejo (la innovación normativa) que sostiene socialmente la legitimación de dicho movimiento.

De esa forma, hemos tratado de radiografiar y diagnosticar un sistema biopolítico (administración de patentes) en el capitalismo global donde se ordena uno de sus núcleos centrales: la producción y acceso al saber tecnocientífico. Una de las carencias del paradigma de la movilidad y del esquema teórico de Urry no deja de ser cierta descripción naturalista de la dinámica de sujetos y objetos sin percibir el papel de la regulación de la misma. Más allá de los recursos concretos que se movilizan o ayudan al traslado, no existe una interpretación (se insinúa pero no se desarrolla) de cómo la reglamentación normativa de la movilidad (las prescripciones sobre sujetos y objetos) imponen un cierto régimen político. La racionalidad política contemporánea, globalizada al máximo, administra las poblaciones en términos de caminos prescriptos y prohibidos tanto para individuos como para objetos (o para agregados y redes heterogéneas). Además de fascinarnos por las trayectorias o rumbos de los grupos sociales, hay que tener en cuenta cómo se gestionan las mismas (su circulación) y las asimetrías en torno a su uso. Las patentes, en este caso, definen los espacios que pueden ser transitados y dibujan los mapas globales de la economía mundial: es la gubernamentalidad del capitalismo cognitivo. ${ }^{16}$

\footnotetext{
${ }^{16}$ Cierto es que el propio Urry reconoce que uno de los procesos que está produciendo una movilidad general de lo social es: "the increasing organization of Science itself on a global basis in which its patterns of growth, commerciali-
} 
Dentro de este desarrollo, sin embargo, hemos insistido en que en las últimas décadas ha sobrevolado un discurso (un esquema epistemológico, cultural o ideológico) que ha ido definiendo cuáles son las estrategias legítimamente válidas en torno a la tecnociencia, un modelo económico del cambio tecnológico: la innovación. De esa forma, la innovación nos permite rastrear la conexión histórica (SXX) entre el campo de la tecnociencia y el campo económico y los modos de justificación para las políticas de mercantilización generalizada (genes, semillas, medicamentos, etc.). ${ }^{17}$ Las diferentes modalidades discursivas históricas (de la innovación descriptiva a la innovación prescriptiva) y evoluciones semánticas están vinculadas a la emergencia de una nueva racionalidad política: el neoliberalismo (Rose, 1996). Una concepción economizada y legalista de la naturaleza y lo viviente (patrimonialidad de la biología) adquirió una cierta legitimidad gracias a prácticas epistémicas y racionalizadoras impulsadas por discursos históricos particulares. En el contexto de la crisis de la década de 1970 y del punto de inflexión (fordismo a postfordismo), el ciclo de innovaciones tecnológicas digitales ayudó a generar un modelo de cambio social privilegiado cuyo consenso político se ha convertido en mayoritario. De alguna manera, lo que se puede observar es que cierto determinismo tecnológico moderno (Smith y Marx, 1996) y la racionalidad económica neoliberal han redibujado la idea de progreso que renace cual ave Fénix pero encarnada en los sistemas de propiedad intelectual e industrial.

La introducción de novedades científicas especializadas que extraen y gestionan la información genética posibilita la propiedad sobre dichos datos, pero el modo planteado de regular tales bienes intangibles mediante patentes constituye una decisión contingente y no necesaria; una elección que está emparentada con la "cultura económica" o con ciertas ideologías sociales hegemónicas. El liberalismo actual y la agresividad empresarial "made in global" están permitiendo una apropiación masiva de los bienes orgánicos que puedan producirse técnicamente. Es la forma histórica favorita de administrar social y legalmente los productos de la genética y las biotecnologías. Ello implica que, simultánea y paralelamente a la mejora y al desarrollo espectacular de las técnicas de manipulación genética (la bioinformática, por ejemplo), se ha producido una movilización del derecho sin precedentes; un trabajo de reglamentación escrupuloso y paciente de estos sectores científico-técnicos. Hay que hacer hincapié en que la ordenación jurídica de las biotecnologías o de la genómica ha sido muchísimo mayor de lo que pudiera siquiera pensarse.

Nuestro ejemplo, el PGH, sirve también como muestra de la formación de un "mercado mundial" (móvil) de genes, tras los mercados internacionalizados de tejidos, productos humanos derivados y otros resultados de la investigación tecnocientífica (transgénicos, semillas, especies vegetales, etc.). Recolectar recursos biológicos o códigos e información científica implica tener acceso a los mismos (en diferentes modalidades y espacios). La valorización económica de las secuencias genéticas, algunas de las cuales alcanzan los miles de millones de dólares, supone la posibilidad misma de un "mercado genético humano" donde los recursos biológicos de nuestra especie transitan "libres" por los circuitos del intercambio global. Las patentes certifican el paso fluido de la naturaleza modificada al mercado (y su circulación emancipada y autónoma), modelando las ciencias de la vida y las dinámicas de investigación. El régimen de patentes dirime el lugar donde se sitúan las formas de vida que llegan al espacio comercial (un anclaje económico) y la aplicabilidad del conocimiento posibilitando su "movilidad mercantil". Los derechos de propiedad intelectual posibilitan, entre otras cosas, no sólo la creación de un mercado donde comerciar con productos de la biología o el laboratorio sino también la misma modificación de la vida.

zation and systems of funding and support involves set of self-organization that do not provide a reductionist mirror of nature, indeed the growth of scientific networks takes various domains further away from equilibria" (Urry, 2008: 28).

17 “'Ciertas nociones] permiten en este sentido, no más considerar la naturaleza como un bloque monolítico, una entidad global y globalizante, sino al contrario como compuesta por una multitud de elementos (de recursos) cuya apuesta es su integración en el seno de una problemática de gestión: se trata de manejar la naturaleza, o el patrimonio natural, en el seno de una economía donde la naturaleza es instrumentalizada en forma de recursos.” (Milanovic, 2011: VIII). 


\section{BIBLIOGRAFÍA}

Boyle, J. (2003) "Enclosing the Genome: What the Squabbles over Genetic Patents Could Teach Us", Advances in genetics. Versión electrónica: http://www.law.duke.edu/boylesite/low/genome.pdf [Accedido $1 / 1 / 2012]$

Callon, M. (1986) "Some elements of a sociology of translation: domestication of the scallops and the fishermen of St Brieuc Bay” en J. Law (ed.) Power, action and belief, pp. 196-233, Londres, Routledge \& Kegan Paul pcl.

(1991) “Techno-economic networks and irreversibility" en J. Law (ed.) A sociology of monsters. Essays on power, technology and domination, pp. 132-161, Londres, Routledge.

CAssier, M. (2002) "Bien privado, bien colectivo y bien público en la era de la genómica”, Revista Internacional de Ciencias Sociales $\mathrm{n}^{\circ} 171$ (Monográfico 'La Sociedad del Conocimiento')

Commoner, B. (1998) “A propósito de la Biotecnología”, en Duran, M. A. y Riechmann, J. (Coords) Genes en el laboratorio y en la fábrica, Trotta, Madrid, pp. 23-31. COMMONER, B. (1998) "A propósito de la Biotecnología", en Duran, M. A. y Riechmann, J. (Coords) Genes en el laboratorio y en la fábrica, Trotta, Madrid, pp. 23-31.

Dutfield, G. y Suthersanen, U. (2005) "DNA Music: Intellectual Property and the Law of Unintended Consequences", Science Studies vol. 18(1), 2005.

Foucault, M. (1995): Historia de la sexualidad, Siglo XXI, Madrid.

(1996): La verdad y las formas jurídicas, Gedisa, Barcelona.

(2006): Seguridad, territorio, población, FCE, Buenos Aires. (2007): Nacimiento de la Biopolítica, FCE, Buenos Aires.

GAUDEMAR, J. P. (1981): La movilización general, La Piqueta, Madrid. (1991): El orden y la producción, Trotta, Madrid.

Heiber, R., Moral, B., Pecharromán, B. y Gordo, A. (2008) "Siniestralidad vial y subjetivación: el coche en la gestión global de la vida y la muerte" en SÁDABA, I. y Gordo, A. (Coords.) Cultura digital y movimientos sociales, Ed. La Catarata, Madrid, pp. 73-97.

Heller, M. y Eisenberg, R. (1998) "Can Patents Deter Innovation? The Anticommons in Biomedical Research ?", Science, vol.280, 1 mayo 1998, pp. 698-701.

Jensen, K. y Murray, F. (2005) "Intellectual Property Landscape of the Human Genome”, Science, vol 310, 14 octubre 2005, pp. 239-240.

KLEIN, J. (2001) "Innovation as discourse", IAMOT Conference, Cambridge.

LARrión, J. (2009) "Los nuevos dueños de la biodiversidad. Tensiones colectivas en torno a los usos y abusos del actual sistema de patentes", en Mendiola, I. Rastros y rostros de la biopolítica, Anthropos, pp. 201-222.

Lasén, A. (2006) “Lo social como movilidad”, Política y Sociedad, vol. 43, no 2, pp. 153-167.

LASh, S. y URRY, J (1987): The End of Organized Capitalism, Madison, WI: University of Wisconsin Press.

Latour, B. (1995): Pasteur. Una ciencia, un estilo, un siglo, Siglo XXI, México DF.

(2005): Reassembling the Social: An Introduction to Actor-Network-Theory, Oxford University Press, Oxford.

Lazzarato, M. (2005) “Biopolítica/Bioeconomía”, Multitudesnº 22, Otoño 2005.

Macleod, C. (1988) Inventing the Industrial Revolution. The English Patent System (1660-1800), Cambridge University Press, Cambridge.

(2009) "Patents for Invention: setting the stage for the British Industrial Revolution?" Empiria n ${ }^{\circ} 18, \mathrm{pp}$. $37-58$.

Mendiola, I. (2006): El jardín biotecnológico, La Catarata, Madrid.

(Ed.) (2009): Rastros y rostros de la Biopolítica. Antrophos, Barcelona.

Milanovic, F. (2011) "Los recursos biológicos. Apuestas transversales de conocimiento, socialización, regulación", Revue d'anthropologie des connaissances, vol.5, n², pp. I-XVIII. 
Mignolo, W. (2009) "Regeneración y reciclaje: descolonizar la ciencia y la biotecnología para liberar la vida" en Mendiola, I. Rastros y rostros de la Biopolítica, pp. 181-199.

Mowery, D. y ZiEdonis, A. (2002) "Academic patent quality and quantity before and after the Bayh Dole act in the United States", Research Policy, vol. 31, pp 399-418.

Noble, D. F. (1987): El diseño de Estados Unidos: la ciencia, la tecnología y la aparición del capitalismo monopolístico, Centro de Publicaciones, Ministerio de Trabajo y Seguridad Social, Madrid.

Nisbet, R. (1980): Historia de la idea de progreso, Gedisa, Barcelona.

Pestaña, A. (1998) "Economía política de la Biotecnología” en Durán, A. y Riechmann, J. (Coords.) Genes en el laboratorio y en la fábrica, Trotta, Madrid, pp. 33-51.

PincheIra, I. (2008) Reseña a 'Nacimiento de la biopolitica: Curso en el Collège de France: 1978-1979', Revista IDEA nº, Chile, pp. 167-170.

Poste, G. (1995) "The case for genomic patenting", Nature, no 378, p. 534.

Pottage, A. (1998) "The Inscription of Life in Law: Genes, Patents, and Bio-politics", The Modern Law Review, Volume 61, Issue 5, pages 740-765, September 1998.

RAI, A. (2002) "Locating Gene Patents within the Patent System", The American Journal of Bioethics, vol. 2, n³, pp. 18-19.

Rifkin, J. (2000): La era del Acceso, Paidós, Barcelona.

Rose, N. (1996) “Governing 'advanced' liberal democracies” en BArry, A., Osborne, T. y Rose, N. (Eds.), Foucault and political reason. Liberalism, Neo-liberalism and Rationalities of Government. Chicago: The University of Chicago Press, pp. 37-64.

Ross, A. (Ed) (1996): Science Wars, Duke University Press, Londres.

SÁDABA, I. (2008) La propiedad intelectual, ¿bienes públicos o mercancías privadas?, La Catarata, Madrid.

SÁDABA, I. (2009) "Conflictos y patentes: derechos privados y bienes públicos" en La construcción de la Bioética (vol. II), Álvarez del Río, A. y Rivero, P. (Coords.), Fondo de Cultura Económica (FCE), México DF, pp. 121-142.

SENNETt, R. (2006): La cultura del nuevo capitalismo, Anagrama, Barcelona.

SHIVA, V. (2003): ¿Proteger o expoliar? Los derechos de Propiedad Intelectual, Intermón Oxfam, Barcelona.

Shreeve, J. (2004): The Genome War: How Craig Venter Tried to Capture the Code of Life and Save the World, Knopf.

SiBILIA, P. (2009): El hombre postorgánico. Cuerpo, subjetividad y tecnologías digitales, FCE, Buenos Aires.

Smith, M. R. y Marx, L. (1996): Historia y Determinismo Tecnológico, Alianza, Madrid.

Sulston, J. y Ferry, G. (2002): The Common Thread: A Story of Science, Politics, Ethics and the Human Genome, National Academies Press.

Swedberg, R. (1991): (Ed.) Joseph A. Schumpeter. The Economics and Sociology of Capitalism, Princeton University Press, New Jersey.

Urry, J. (2007): Mobilities, Polity Press, Cambridge.

URRY, J. y Elliot, A. (2010): Movile lives, Routledge, Londres.

VVAA (2005): ¿Un mundo patentado? La privatización de la vida y el conocimiento, Fundación Heinrich Böll, El Salvador. [http://www.boell-latinoamerica.org/download_es/Libro_biopolitica.pdf]

Warshofsky, F. (1994): The Patent Wars. The battle to own the world's technology, John Wiley\&Sons, Nueva York.

Waldby C. y Mitchell R. (2006): Tissue economies: Blood, organs and cell lines in late capitalism, Durham, Duke University Press 